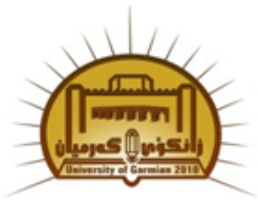

Available online at http://jgu.garmian.edu.krd

Journal of Uni versity of Garmian

https://doi.org/10.24271/garmian.1032

\title{
The Role of pumpkin Seed oil in Healing of Wounds in Mice
}

\author{
Adel Abas Safar \\ Veterinary Directorate of Garmian
}

\section{Article Info}

Received: January, 2019

Revised:February,2019

Accepted:April,2019

\section{Keywords}

Pumpkin, seed oil, woundhealing, mice.

\section{Corresponding Author}

adelabas47@gmail.com

\begin{abstract}
This study was conducted to explore the role of pumpkin seed oil (PSO) ofcucurbitapepo ,as alternative of traditional medicinal treatment for manage wound healing in mice .Firstly, the oil of cucurbitapepo (pumpkin seed oil) obtained by hot extraction method with $n$-hexane solvent .Forty male Balb- c mice were coetaneous induced surgical wound on the back region bilaterally .Theywere divided into four equal groups and treated topically as following . Group one (G1) treated with pumpkin seed oil, group tow (G2) treated with MEBO, group three $(\mathrm{G} 3)$ treated with combination of pumpkin seed oil plus MEBO. While group four (G4) didn't received any treatment and considered as control. Clotting time, platelet count, blood glucose, insulin activity, white blood cells count, red blood cells count, differential white blood cells count, pro thrombin time, thrombin time and fibrinogen level, were assessed after one day of induced wound and after complete wound healing in all experimental animals. The wounds were followed up through measuring their diameters, photographically and histological (through obtaining skin biopsy after 4, $6,8,10 \mathrm{days}$ and so on of incision tillhealing. There were no statisticaldifferences at $\mathrm{p}<0.05$ in clotting time, platelet count, red blood cells count and pro thrombin time between the values measured after one day of incision when compared to the values measured after healing in all experimental groups. The diameter of wounds decreasesi.e. wound healed proportionally with the time of treatment. Histological appearance of the wound of experimentalgroupsexhibited progression in wound healing which was taking410 days after treatment. All healed wounds of various groupsshamed decrease in inflammatory cell with collagen infiltration in the dermis and complete regeneration of the epithelial cells in the epidermis.
\end{abstract}

\section{Introduction}

Wounds are physical injuries that result in an opening or break of the skin that cause disturbance in normal skin anatomy and function [1]. The process of wound healing occurs in different phases such as coagulation, epithelization, granulation, collegenationand tissue remodeling [2]. 
Collagen, the major component which strengthens and supports extracellular tissue, contains substantial amounts of hydroxyproline, which has been used as a biochemical marker for tissue collagen [3]. Decreases in growth factors responsible for tissue repair such as platelet derived growth factor (PDGF) and transforming growth factor-b (TGF-b) documented alterations in MMP (matrix metallo proteinases) expression and activation are consistent with a pattern associated with increased degradation of newly formed ECM (extracellular matrix).

Many factors can influence on wounds healing are essential for developing better therapeutic option for wound treatment [4]. Improper diet and infection at wound site drugs, elderly age, insufficient oxygen supply and tissue perfusion to wound area, diabetes and other disease condition. The use of herbal remedies individually or in combination with standard medicines has been used in various medical treatises for the cure of different diseases.

Pumpkin is one of the well-known edible plants and has substantial medicinal properties due to the presence of unique natural edible substances. It contains several phytoconstituents belonging to the categories of alkaloids, flavonoids, and palmitic, oleic and linoleic acids. Our study designated to Investigating the effect of pumpkin seeds oil for treatment wounds in mice. Hopefully, it will facilitate the development of strategies to improve the rate of tissue repair.

\section{Materials and Methods}

\section{Pumpkin (cucurbita. pepo)}

Fruit purchased from local market Iraq during October 2016. And extracted by n-hexane according to [5].

\section{The Animals}

Forty male Balb-C mice, with body weight ranged 20-30 grams and age 8-12 week, purchased from animal house - Ministry of Technology. They were bred under optimum condition of ventilation, temperature $25{ }^{\circ} \mathrm{C}$ and dark and light cycle 12/12. The animals were fed on special formula feed pellets and given water ad libitum throughout the experiment, each 6 mice were housed in a plastic cage 20x15x15 cm dimensions containing hard-wood chip as bedding. They were left for two weeks to acclimatization before starting of the experiment.

\section{Expermental design}

The experiment is conducted according to standard ethics take inconsideration the welfare of animals (6).

\section{Clinical study}

Forty (40) Balb $-\mathrm{C}$ male mice, they were divided equally into four groups, and assigned as.Group 1, treated with pumpkin seed oil topically , and mice equally subdivide into two sub groups one of them left till healing but the other mice subjected to biopsy. Group2, treated daily with derma betacream topically, Group 3.reated with combination of derma beta creamplus pumpkin seed oil topically Group 4: was not treated with any materials and considered control group .The mice of G2, G3 and control also divided equally and subjected to biopsy as in G1.

\section{Phytochemical analysis of pumpkin seed oil} Were carried out according to [7, 8]. Briefly, detection of tannins. Ten grams of powder added to $50 \mathrm{ml}$ distilled water filtered, and few drops of $1 \%$ lead acetate were added, the appearance of gelatinous white precipitant represented a good indicator for tannins.

Saponin.The appearance of a big foam for a long time after stirring the aqueous solution of powder in test tube indicated saponin availability.

Flavinoids.Ten grams of powder in $10 \mathrm{ml}$ of $95 \%$ ethanol then filtered, while Solution B was prepared by adding $10 \mathrm{ml}$ of $50 \%$ ethanol to 10 $\mathrm{ml}$ of potassium hydroxide $(\mathrm{KOH})$, two equal volumes of solution $\mathrm{A}$ and solution $\mathrm{B}$ were mixed. Appearances of yellow color referred to flavonoid's existence. 
Phenols.Ten grams of powder was added to 50 $\mathrm{ml}$ of distilled water heated till boiling; then left to cool, and filtered, $1 \%$ of Ferric chloride solution $(\mathrm{FeCl} 3)$ was added to the filtered solution. Appearance of blue green color referred to the phenolic.

Resins. $50 \mathrm{ml}$ of $95 \%$ ethyl alcohol was added to $5 \mathrm{~g}$ of seed powder $\mathrm{o}$, the mixture was boiled in water bath for 2 minutes, then cooled the mixture filtered, $10 \mathrm{ml}$ of distilled water containing $4 \%$ $\mathrm{HCl}$ was added to the filtered solution, the appearance of turbidity referred to resins.

Glycosides $5 \mathrm{ml}$ of Fehling's reagent with $5 \mathrm{ml}$ of aqueous solution of seed powder or, incubated in water bath for 10 minutes. The appearance of red precipitantreferred to existence of glycosides. Cumarin. Two $\mathrm{ml}$ of watery solution of seed powder was put in a test tube and covered with a filter paper and placed in water bath, heated till boiling. The appearance of green-yellow color referred to the presence of coumarins.

Steroids.One grams of seed powder was dissolved in 1-2 $\mathrm{ml}$ of chloroform, one drop of acetic acid anhydride was added, and then one drop of concentrated sulphuric acid (H2SO4) also added, appearance of a blue green color represented steroids availability.Alkaloids. Ten grams of powder dissolved with $50 \mathrm{ml}$ of distilled water which acidified with $4 \% \mathrm{HCl}$ solution was boiled, after cooling the solution was filtrated, add the Pecric acid reagent green precipitant referred to alkaloid's existence.

Platelets count carried out according to [9]. It was measured by using hemocytometer and diluting fluid was ammonium oxalate. The blood was sucked up to the level of 0.5 and completed with ammonium oxalate solution to the level 101. The pipette was shaken for several minutes. Both sides of hem cytometer were filled with diluted blood and covered with cover slide placed in a Petri -dish containing a piece of wet filter paper was counted in 4squares WBCs.

Determination of clotting time (per minute) using micro hematocrit capillary tubes (without heparin), inserted into inner canthus each 60 second a piece of capillary tub was broken, the appearance of strand like form means clotting of blood.

Pro thrombin time (PPT). Freshly blood was collected by taking it into 0.11 mole trisodium citrate in the ratio of 9 parts of blood to 1 part of anticoagulant. Plasma was analyzed within $2 \mathrm{~h}$ of preparation. Fibrinolysis diagnostic testing in the assessment of thrombosis and hemostasis.

Thrombin time.Blood/anticoagulant ratio: $4.5 \mathrm{ml}$ of blood for $0.5 \mathrm{ml}$ of sodium citrate $2 \mathrm{H} 2 \mathrm{O} .109 \mathrm{~m}$ simultaneously start a timer and record the clotting time Adding thrombin gently till back and forth near to horizontal position until a solid gel clot appears.

Fibrinogen level were assessed according to procedures recommended by [10] Dilute plasma 1/10in diluting buffer (vialR2) this dilution correspond to a fibrinogen concentration in the test tube between 200to400mgldl diluted plasma $0.2 \mathrm{ml}$ incubate for $2 \mathrm{mint}$ at $37^{\circ} \mathrm{c}$ fibrinogen $0.2 \mathrm{ml}$ simultaneously start a timer and record the clotting time.

Clinical observation, performing bilateral cutaneous circular shape wounds with $8 \mathrm{~mm}$ in diameter on the back, by use surgical instrument with used ruler to measure the diameter of skin wounded two day by two day at fourth day, six, eight, ten and twelve day respectively.

Measurement the diameter and histopathological observation of wounds along the period of the study were performed by biopsy were obtained at $4,6,8,10$ day of experiment and till complete healing of wounds.

\section{Oil extraction}

Fifty grams of seeds powder was put in the 1liter volumetric flask, $1000 \mathrm{ml}$ of $95 \% \mathrm{n}$-hexane was poured on, mixed and extracted by magnetic stirrer at $40^{\circ} \mathrm{C}$ for 36 hours at darken hood. After that filtered with gauze to get rid the residue then extra filtrated by filter paper 0.8 . The filtrate dried up by rotary evaporates at $60^{\circ} \mathrm{C} / 90 \mathrm{rpm}$. The final extract was kept in liquid nitrogen at 170until use. 


\section{Blood Collection}

Blood collected from all experimental animals through heart puncture under general anesthesia.

\section{Statis tical Analysis}

Data were analyzed by using SPSS, version 21 . Statistical analysis of data-based analysis of variance (ANOVA) two ways and significances $\mathrm{P}<0.05$. Least square differences (LSD) used for comparing between means of all parameters of all experimental groups [11]

\section{Results}

1. The yield Extract of Cucurbitape po:

The yield extract was $58 \%$ oil. The oil showed no changes in color, consistency, no smell odor and there were no fungal and bacterial growth. Pumpkin seed oil exhibited highly physical and biological stability (12) since there were no undesirable changes occurs during our study. They contained the following phytochemicals; steroids, flavonoids and saponin, while alkaloids, phenol, terpenoids, resins, tannins, glycosides and coumarins didn't appear.

2. Clotting time (second)

Clotting time of all experimental animals in different groups involved in the study, showed no significance $\mathrm{P}>0.05$ differences, as table (1).

3. Platelets count

After wounds healing showed no significant $\mathrm{p}<$ 0.05 change when compared to the one day after incision value in all experimental, as table (1).

\section{Pro thrombin Time}

show no significant $\mathrm{p}<0.05$ chang between and within groups levels, as table 2 .

\section{Thrombin Time}

There was no significant $\mathrm{p}<0.05$ changes within groups along the period of study, but the only G1(PSO) showed significant $\mathrm{p}<0.05$ decrease both after one day of incision and after healing shown in table 2 .

\section{Fibrinogen Level}

There was no significant $\mathrm{p}<0.05$ changes between fibrinogen blood level after one day of incision and after healing in all experimental groups, but only fibrinogen level of group3 (MEBO+PSO) showed significant $\mathrm{p}<0.05$ increase after one day of incision and after wound healing when compared to control fibrinogen blood level at the same period shown in table 2 .

\section{The visual observation and diameter} meas ure ment of wound

The wound healing of the experimental animals' groups, was observed through measuring the diameter and flowed up photographically and histologically. Bilateral Circular wounds with diameter 8-millimeter were incised initially in the skin (back region) of all experimental animals. Figure 1

Wound after four days of treatment: The all experimental animals' groups, showed no significant difference $\mathrm{p}<0.05$ in the wound diameter. Figure 2

After six days of treatment, the all animals of experimental group, showed significant $\mathrm{p}>0.05$ decrease in wound diameter. Figure 3

After eight days of treatment: The only G2 (MEBO) and control showed significant decrease in diameter when compared to G1 and G2. Figure 4

After ten days of treatment, the wounds of treated groups G1, G2 and G3, showed statistical p>0.05 reductions in wound diameter, when compared to wound diameter of G4control. Figures 5

\section{Result and Discussion}

His tologically follow up of wound Healing After 4 days of incision: All groups show the same histological appearance. They showed intensive inflammation and infiltration of inflammatory cell mainly lymphocyte and neutrophil (MNCs), and highly infiltration of 
lymphocyte and macrophage and less amount of neutrophil, Figure 3-1

All after 6 days. Groups showed severe infiltration of inflammatory cells particularly neutrophils in the incision site. Figure 3.2

All after 8-10 days groups showed same wound healing with collagen infiltration in the dermis and complete regeneration of the epithelial cells in the epidermis. Figure 3.3.

\section{Discussion}

This study has revealed that oil from pumpkin seeds extracted by $n$-hexane is an important source of many healthy components such as antioxidant and antimicrobial agents. The presence of sterols and polyunsaturated fatty acids in pumpkin oil make it an excellent in pharmaceutics and cosmetics preparation which would provide potential protection against skin affection, e.g. dermatological wound. The findings of our study revealed also that cutaneous wound healing in mice treated with pumpkin oil extract was better than untreated(control) or reference groups (treated with mebo) by the means of morphometric and histological appearance.

Pumpkin seed oil exhibited highly physical and biological stability since extraction at early 2017 till now, the thought, may be due to the environment of the storage in liquid nitrogen [13] Pumpkin Flavonoid anti-inflammatory activity, anti-microbial. Pumpkin polysaccharide exhibiter higher cytoprotective effect, indicating that could enhance the cytoprotective effect [14]. Antibacterial characteristics of pumpkin seed oil when applied on infected wounds with pathogenic bacteria Sauers that treated infected wounds completely within the course time of treatment. Flavonoids, one of the phytoconstituent were found in pumpkin which contribute antibacterial effects as recorded in different studies [15]. Use of these therapies is restricted by their pharmacokinetic properties, secondary failure rates and accompanying side effects, onion bulb (A//iumcepa) and cloves of garlic (A//iumsativum) have long been used as dietary supplement for traditional treatment. Former is used as stimulant, diuretic and expectorant [16].

A dynamic balance between endothelial cells, thrombocytes, coagulation, and fibrinolysis regulates hemostasis and determines the amount of fibrin deposited at the wound site, thereby influencing the progress of the reparative processes [17]. Wound healing is a complex and dynamic process of restoring cellular structures and tissue layers in damaged tissues as close as possible to its normal state. Wound contracture is a process that occurs throughout the healing process, commencing in the fibroblastic stage whereby the area of the wound undergoes shrinkage. The final phase of wound healing, the wound undergoes contraction resulting in a smaller amount of apparent scar tissue [18]. One of major processes involved in the early stages of healing is related to the inflammatory response [19]. The initial inflammatory response involves the recruitment of cells that fight potential bacterial contamination of the wound and activate cytokine secretion to activate dermal and epidermal processes [20] .Pumpkin Flavonoid anti-inflammatory activity , anti-microbial[21] .Pumpkin polysaccharide exhibiter higher cytoprotective effect, indicating that could enhance the cytoprotective effect[22] .The wound-healing property of pumpkin seed oil may be attributed to the phytoconstituents present in the plant and the faster process of wound healing could be a function of this phytoconstituents. The presence of medicinally active constituents like alkaloids, flavonoids, saponin, and tannins. They are well known in showing medicinal activity as well as exhibiting anti-inflammatory activity [23].

Various plants of wound healing property and also contain flavonoids as active constituents have been found. Tannins promote the wound healing through several cellular mechanisms, chelating of the free radicals and reactive species of oxygen, promoting contraction of the wound 
and increasing the formation of capillary vessels and fibroblasts. The process of wound healing is promoted by several natural products [24].

Oil from pumpkin seeds extracted by cold pressure is an important source of many healthy components such as antioxidant and antimicrobial agents. Furthermore, the presence of tocopherols, sterols and polyunsaturated fatty acids in pumpkin oil make it an excellent drug in pharmaceutics and cosmetics which would provide potential protection against skin problem, e.g. dermatological wound. In fact, findings revealed also that cutaneous wound healing in rats treated with pumpkin oil extract was better than untreated or reference groups by the means of macroscopic, morphometric and histological data [25].

\section{Conclusions}

We have got promising response for healing the wounds; this may be encouraged for say question for closed trials. Pumpkin works as an antiseptic, astringent and anti-inflammatory and provides detoxifying, soothing and toning support. CucurbitaPepo, pumpkin seed oil a powerful antioxidant and mild retinoic acid substitute, we found that all experimental group treated with $\mathrm{PSO}$, and PSO+MEBO showed increase in fibrinogen levels, in contrast with the animals of control groups, they may be due to potentiality of PSO in mantle the fibrin level which is necessary for wound healing whereas fibrinogen is the precursor of fibrin.

Our study finding, generally there were significant decrease in prothrombinetime, the thought the PSO and MEBO have counteracted and promote the potential function of thrombin in repair vessel wall damage, and enhance to release of blood platelet in wound healing.

\section{Acknowle dgements}

Praise is to almighty Allah, the most gracious, the most merciful, for giving me strength to accomplish this work. My deep gratitude should go to all members of department of pharmacology for their cooperation and help.

\section{References}

1- Al-Bid, $\quad$ M.R.

Zurrzusammamseturungderabschla

(1985).

membrane in phoenix dactyliferabooks. Wurzbury University.

Wuzzburg F.R. of Germany.Pp:643-689.

2- Athieu D, Linke J-C, Wattel F. (2006). Non-

healing wounds. In: Handbook on Hyperbaricmedicine, Mathieu DE, edit. Netherlands: Springer, p.335-355.

3- Bejon P, Andrews L, Hunt-Cooke A, Sanderson F and Gilbert SC, (2006). Calculation phytochemical analysis technique of plant analysis. Jul;4(8):118-26.

4- Boaduo NK, Katerere D, Eloff JN, Naidoo V. (2014). Evaluation of six plant species used traditionally in the treatment and control of diabetes mellitus in South Africa using in vitro methods. Pharm Biol.10 (5):552-578.

5- Cherry GW, Hughes MA, Leaper DJ. (2000). Wound healing, oxford University press, Oxford, 132.

6- Chung J, Ou X, Kulkarni RP, Yang C.PLoS One. (2015). Counting White Blood Cells from a Blood Smear Using Fourier Ptychographic Microscopy 17; 10(7).

7- Global Burden (2016). Statistical methods applied to experiments agriculture and biology. 5th ed. Ames, Iowa: Iowa State University Press.

8- Harborne,J,B.(1984). Phytochemical methods a guide to modern technique of plant analysis. Champman and Hill. London .UK. Pp: 16-35.

9- John, W. (2014). Ethical and Animal Welfare Consideration in Relation to Species Selection for Animal Expermintation. Animals (basel).;4(4):729-741.

10- Koh TJ, DiPietro LA. (2011). Inflammation and wound healing: the role of the macrophage Expert Rev Mol Med. 
11- Komarcevic A: (2000). The modern approach to wound treatment. Med Pregl; 53: 363 368.

12- Leone, S., Ottani, A., \&Bertolini, A. (2007). Dual acting anti-inflammatory drugs. Current Topics in Medicinal Chemistry books, Pp:132-165.

13- Marchetti, G., patracchiniD, P., Gemmati, V.,DeRosa, M., Pinotti, G., Rodorigo, A., Casonato,.,Girolami, A. and Bernardi, F.(1992). Detection of two missense mutations and characterization of a repeat polymorphism in the factor VII gene (F7). Hum Genet. 89(5): p. 497-502.

14- Mirza R, DiPietro LA, KohTJ.Am J Pathol. (2009). Selective and specific macrophage ablation is detrimental to wound healing in mice. The American journal of pathology,cellular and molecular biology of disease, Dec; 175(6):2454-62.

15- Mittal A, Sardana S, Pandey A (2013). Herbal boon for wounds. International Journal of Pharmacy and Pharmaceutical Sciences, 5(2): 565-676.

16- Napavichayanun S, Aramwit P.J BiomaterSciPolym Ed. (2017) Jun; 2: Effect of animal products and extracts on wound healing promotion in topical applications: a review. 28 (8):703-729.

17- Nayak BS, Sandiford S, Maxwell A. (2007). Evaluation of the wound-healing activity of ethanolic extract of MorindaCitrifolia L. leaf, Ecam; 127:1-6.
18- Odebiyi, O. and Sofowora, E.A. (1978). Phytochemical screening of Nigerian medical plants II. Lloydia., 41:2234-246.

19- Orenstein SB, Saberski ER, Klueh U, KreutzerDL, Novitsky YW, (2010). Effects of mast cell modulation on early host response to implanted synthetic meshes Hernia journal, 14(5):304-328.

20- Rizaullah (2018). A review on ionic liquids as perspective catalysts in transesterification of different feedstock oil. biodiesel, vol. 266, pp. 673-686,

21- Roger Adams and Geissman TA. (2011). Chemistry of flavonoid compounds. Macmillan. publication Journal of the American Chemical Society, 61 (8): 132212.

22- Siller-Matula JM, Schwameis M, Blann A, Mannhalter C, Jilma B: (2011). Thrombin as a multi-functional enzyme. Focus on in vitro and in vivo effects books. Thromb Haemos.Pp323-398.

23- Spicknall IH, Foxman B, Marrs CF, Eisenberg JNS (2013). A modeling framework for the evolution and spread of antibiotic resistance books: literature review and model categorization.pp (232-304).

24- Strodtbeck, F. (2001). Physiology of Wound Healing: New Born Infants, Nurs Rev, 1: 43 -52 .

25- Wayne PA, (1998). Procedures for the collection of diagnostic blood specimens by venipuncture: approved standards 4th Ed, NCCLS, North calorinapp(734-767). 
Table1: Clotting Time/ second and platelet count/ mm3

\begin{tabular}{|c|c|c|c|c|}
\hline GROUPS & $\begin{array}{c}\text { CLOTTING } \\
\text { TIME AFTER } \\
\text { DAY ONE OF } \\
\text { WOUND } \\
\text { S.E } \pm \text { M }\end{array}$ & $\begin{array}{c}\text { CLOTTING } \\
\text { TIME AFTER } \\
\text { WOUND } \\
\text { HEALING } \\
\text { M } \pm \text { S.E }\end{array}$ & $\begin{array}{c}\text { PLATELET COUNT } \\
\text { AFTER } \\
\text { DAY ONE OF WOUND } \\
\text { M } \pm \text { S. E }\end{array}$ & $\begin{array}{c}\text { PLATELET COUNT } \\
\text { AFTER } \\
\text { WOUND HEALING } \\
\text { M } \pm \text { S.E }\end{array}$ \\
\hline $\begin{array}{c}\text { G1 } \\
\mathbf{n}=\mathbf{5}\end{array}$ & 60 & 60 & $\begin{array}{c}365.31 \times 106 \pm 538.17 \times 103 \\
\mathrm{ABa}\end{array}$ & $\begin{array}{c}400.00 \times 106 \pm 455.9 \times 103 \\
A \quad A\end{array}$ \\
\hline $\begin{array}{c}\text { G2 } \\
\mathrm{n}=5\end{array}$ & 60 & 60 & $\begin{array}{c}290.60 \times 106 \pm 473.60 \times 103 \\
\mathrm{Ba}\end{array}$ & $\begin{array}{c}241.33 \times 106 \pm 265.34 \times 103 \\
\text { B } \quad \text { A }\end{array}$ \\
\hline G3 & 60 & 60 & $433.62 \times 106 \pm 299.66 \times 103$ & $310.66 \times 106 \pm 634.75 \times 103$ \\
\hline $\begin{array}{c}\text { PSO+MEBO } \\
n=5\end{array}$ & & & $\mathrm{~A} \quad \mathrm{a}$ & A $\quad$ B \\
\hline G4 $\underset{n=5}{\text { Control }}$ & 60 & 60 & $\begin{array}{c}254.03 \times 106 \pm 395.49 \times 103 \\
\mathrm{CBa}\end{array}$ & $\begin{array}{c}301.33 \times 106 \pm 383.4 \times 103 \\
\text { A } A\end{array}$ \\
\hline
\end{tabular}

-1LSD of platelet count $=101.36 \times 103 \quad$ - capital letters denote significant $p<0.05$ differences among groups. -small letters denote significant $\mathrm{p}<0.05$ differences within groups.

Table2: Pro thrombin Time / second, Thrombin Time/second, Fibrinogen (mg/d L) Level

\begin{tabular}{|c|c|c|c|c|c|c|}
\hline Groups & $\begin{array}{l}\text { Pro thrombin } \\
\text { after one Day } \\
\qquad \mathrm{M} \pm \text { S.E }\end{array}$ & $\begin{array}{c}\text { Pro } \\
\text { thrombin } \\
\text { After } \\
\text { Healing } \\
\text { M } \pm \text { S.E } \\
\end{array}$ & $\begin{array}{c}\text { Thrombin } \\
\text { after one } \\
\text { Day } \\
\text { M } \pm \text { S.E }\end{array}$ & $\begin{array}{c}\text { Thrombin } \\
\text { After healing } \\
\text { M } \pm \text { S.E }\end{array}$ & $\begin{array}{c}\text { Fibrinogen } \\
\text { after one } \\
\text { Day } \\
\text { M } \pm \text { S.E }\end{array}$ & $\begin{array}{c}\text { Fibrinogen } \\
\text { After healing } \\
\text { M } \pm \text { S.E }\end{array}$ \\
\hline $\begin{array}{c}\text { G1 } \\
\text { PSO } \\
\text { n=5 }\end{array}$ & $\begin{array}{c}11.66 \pm 0.32 \\
\mathrm{Aa}\end{array}$ & $\begin{array}{c}11.22 \pm 0.06 \\
\mathrm{Aa}\end{array}$ & $\begin{array}{c}25.46 \pm 0.63 \\
\mathrm{Ba}\end{array}$ & $\begin{array}{c}27.63 \pm 0.11 \\
\text { B } \quad \text { a }\end{array}$ & $\begin{array}{c}277.33 \pm 19.9 \\
1 \\
\mathrm{Ba}\end{array}$ & $\begin{array}{c}293.33 \pm 20.48 \\
\text { A }\end{array}$ \\
\hline $\begin{array}{c}\text { G2 } \\
\text { MEBO } \\
\mathbf{n}=5\end{array}$ & $\begin{array}{c}11.63 \pm 0.34 \\
\mathrm{~A} \quad \mathrm{a}\end{array}$ & $\begin{array}{c}11.77 \pm 0.14 \\
\mathrm{Aa}\end{array}$ & $\begin{array}{c}33.63 \pm 1.58 \\
\mathrm{Aa}\end{array}$ & $\begin{array}{c}33.63 \pm 0.57 \\
\text { A } \quad \mathrm{a}\end{array}$ & $\begin{array}{c}237 \pm 24.37 \\
\mathrm{Da}\end{array}$ & $\begin{array}{c}242.66 \pm 23.70 \\
\text { C } a\end{array}$ \\
\hline $\begin{array}{c}\text { G3 } \\
\text { PSO+MEBO } \\
n=5\end{array}$ & $\begin{array}{c}12.43 \pm 0.58 \\
\mathrm{~A} \quad \mathrm{a}\end{array}$ & $\begin{array}{c}12.11 \pm 0.15 \\
\mathrm{~A} \quad \mathrm{a}\end{array}$ & $\begin{array}{c}35.70 \pm 1.44 \\
\text { A } \quad \text { a }\end{array}$ & $\begin{array}{c}35.36 \pm 0.39 \\
\text { A } \quad \text { a }\end{array}$ & $\begin{array}{r}330.00 \pm 9.64 \\
\text { A } \quad \mathrm{a}\end{array}$ & $\mathrm{A}^{329 \pm 10.52}$ a \\
\hline $\begin{array}{c}\text { G4 } \\
\text { Control } \\
\text { n=5 }\end{array}$ & $\begin{array}{c}11.45 \pm 0.21 \\
\mathrm{~A} \quad \mathrm{a}\end{array}$ & $\begin{array}{c}11.90 \pm 0.08 \\
\mathrm{Aa}\end{array}$ & $\begin{array}{c}34.33 \pm 1.45 \\
\mathrm{~A} \quad \mathrm{a}\end{array}$ & $\begin{array}{c}33.06 \pm 1.00 \\
\text { A } a\end{array}$ & $\begin{array}{c}298 \pm 0.88 \\
\text { CBDa }\end{array}$ & $\begin{array}{c}246.00 \pm 17.00 \\
\text { BCa }\end{array}$ \\
\hline
\end{tabular}

LSD of pro thrombin=1.77, LSD of thrombin $=3.42$, LSD of fibrinogen $=43.09$ - capital letters denote significant $\mathrm{p}<0.05$ differences among groups. - small letters denote significant $\mathrm{p}<0.05$ differences within groups.

4.7 The visual observation and diameter measurement of wounds:

The wound healing of the experimental animals groups, was observed through measuring the diameter and flowed up photographically and histologically. Bilateral Circular wounds with diameter 8 millimeter were incised initially in the skin (back region) of all experimental animals. (Figure 1) 


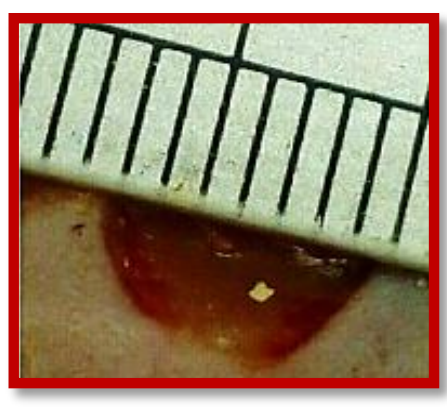

Figure 1: Circular wounds with diameter $8 \mathrm{~mm}$ incised in all experimental groups.

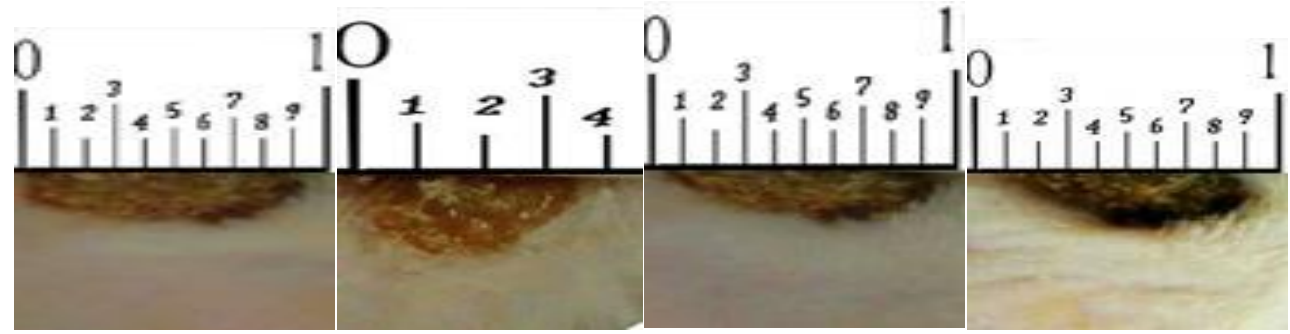

Figure 2: Wounds of all experimental groups after 4 days of treatment (a)G1 (PSO) pumpkin seed oil (b)G2 (MEMO).(c)G3 pumpkinseed oil plus ointment (PSO+MEBO). (d)G4 (control) show no significant chang.

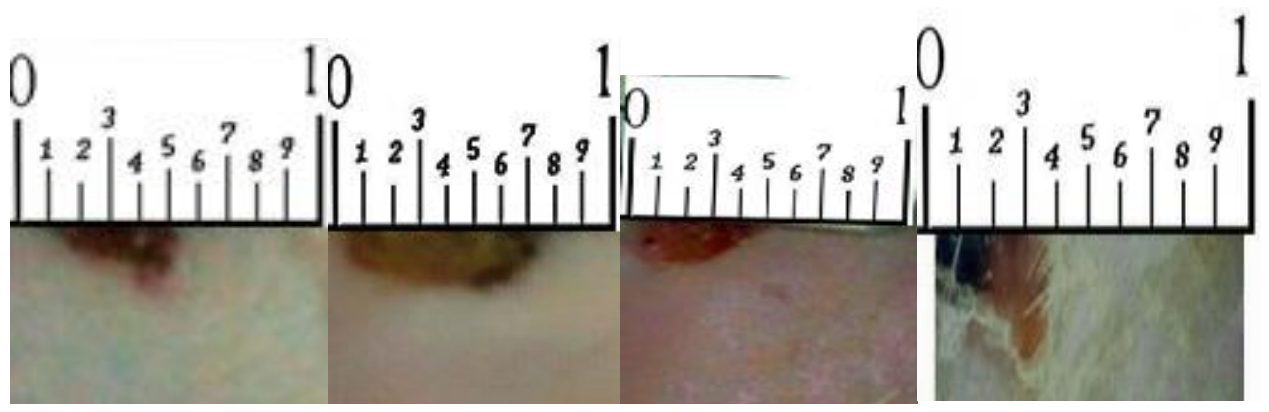

Figure 3: Wounds of all experimental groups after 6 days of treatment. (a)G1 (PSO) .(b)G2 (MEBO).(c)G3 (PSO+MEBO). (d)G4 (control) show decrease in wound healing.

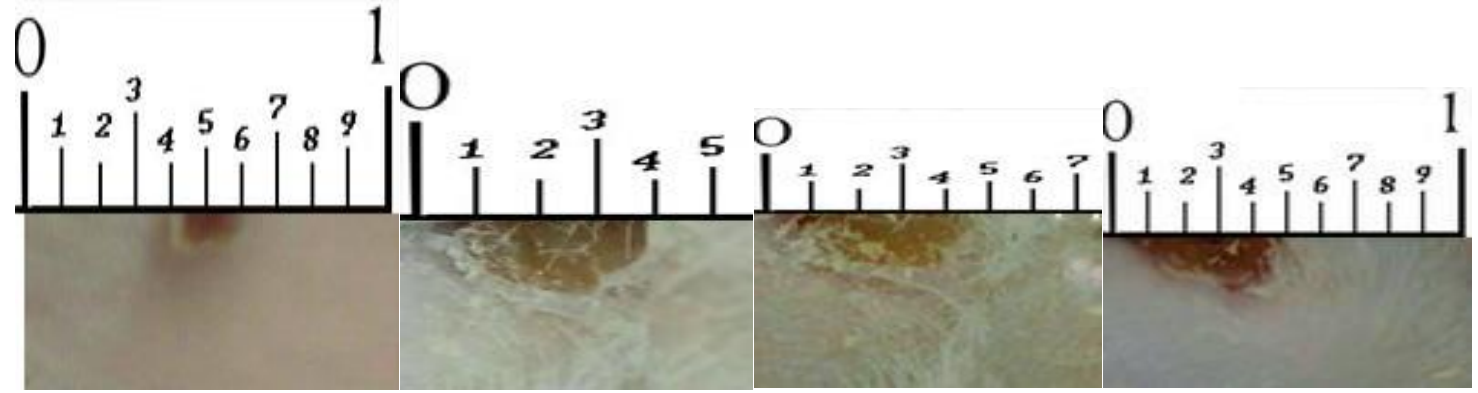

Figure 4. Wounds of all experimental groups after 8 days of treatment. (a)G1 (PSO). (b)G2 (MEMO).(c) (PSO+MEBO). (d) (Control). 


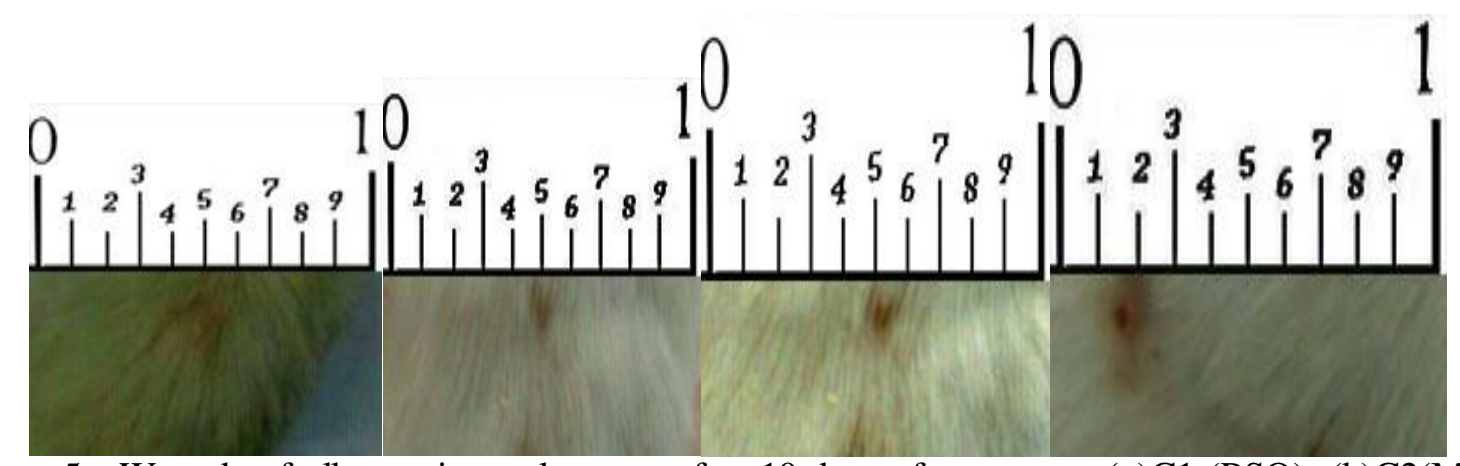

Figure 5: Wounds of all experimental groups after 10 days of treatment. (a)G1 (PSO). (b)G2(MEMO). (c)G3 (PSO+MEBO). (d)G4 (control).

Table 3: Wounds diameter / millimeter treated with PSOMEBO and PSO+MEBO.

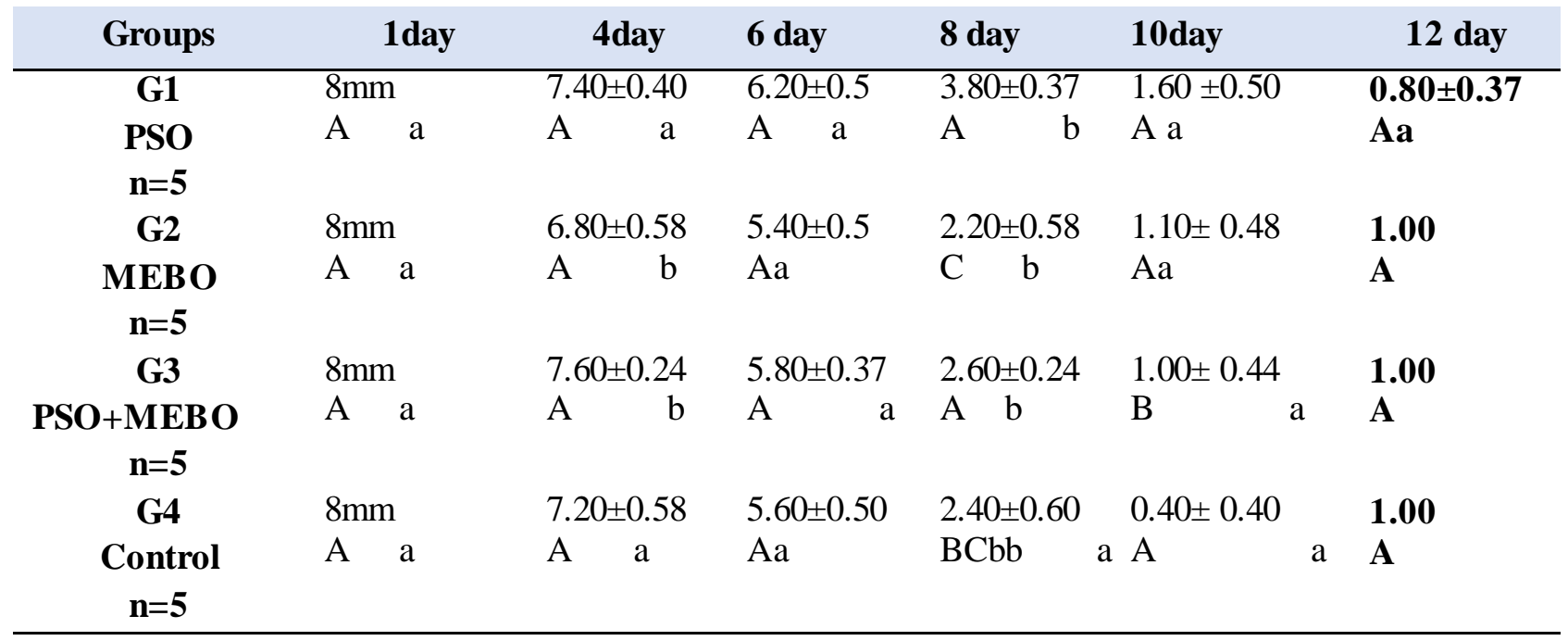

-LSD of wound healing=1.33 -capital letters denote significant $\mathrm{p}<0.05$ differences among groups. Small letters denote significant $\mathrm{p}<0.05$ differences within groups.

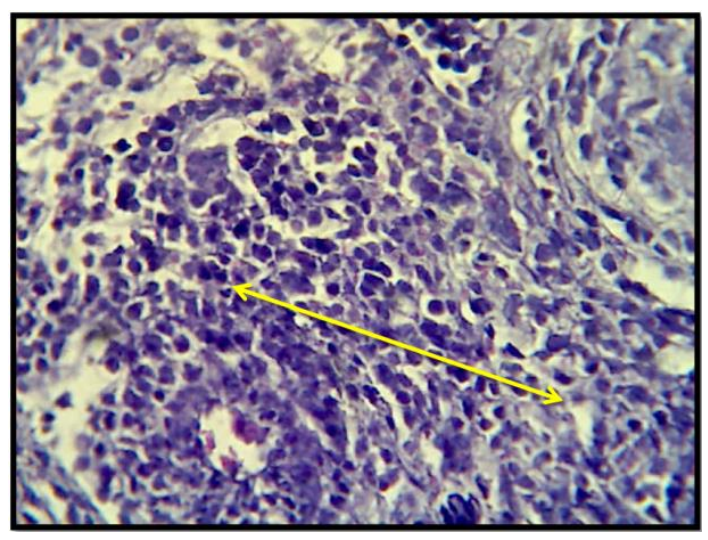

Figure .3.1. Micrograph of injured skin of mice after 4 days of wound observe infiltration of MNCs ),$(\mathrm{H} \& \mathrm{E} \mathrm{X100})$. 


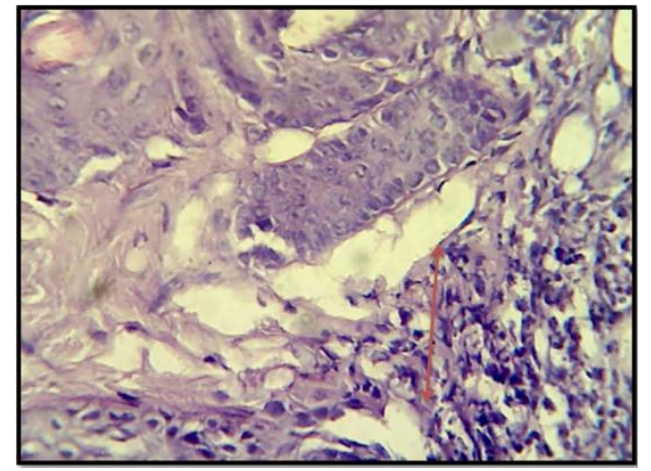

Figure 3.2. Micrograph in the injured skin of mice in all groups after six days observe neutrophil iffiltration $(\quad),(\mathrm{H} \& \mathrm{E} X 100)$.

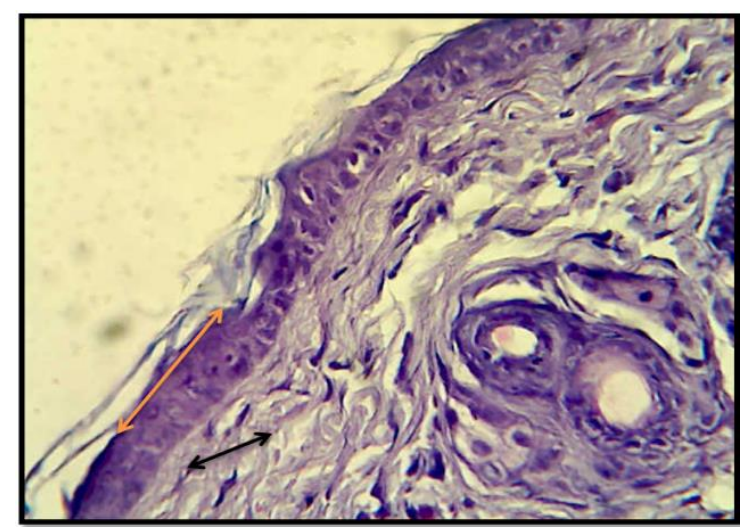

Figure 3.3. Micrograph in the injured skin of mice after 8-10 days, observed complete regeneration of epithelial cells $(\longleftrightarrow$ ) less amount of inflammatory cells and collagen in dermis $(\longleftrightarrow)$, ( H \&E X400). 